\title{
7. Ritual in the Law of Electoral Democracy
}

\author{
Graeme Orr ${ }^{1}$
}

\section{Theorising the law of democracy}

For all its concern with power, prestige and politics, public law can be an earnest and colourless topic. The corner of public law I inhabit is the law of politics, especially electoral democracy. It is particularly dominated by a concern with process. On top of that, it is not well theorised. In part, this is because it is an emerging sub-discipline. It has been jointly sired by constitutional and administrative law, and by that branch of political science concerned with electoral systems and behaviour. But the law of politics is also under-theorised because it is seen as an essentially pragmatic venture in which even symbolism and rhetoric are sublimated. The High Court's occasional venture (or adventure) aside, $^{2}$ whether it is made ad hoc by judges or, as is more typical, explicitly by Acts of Parliament or even inferentially by electoral administrators, electoral law is proudly pragmatic.

This essay is an attempt to rectify that under-theorising of the law of electoral politics. By theorising, I mean asking the 'why' or 'what for' questions. By the law of electoral politics, I mean the rules lain down, and institutions and systems set up, to govern democracy through the process of renewing elective offices and other forms of popular voting, such as referendums. Here, I want to stake a claim for the importance of the concept of ritual in how we understand this field, particularly in considering what elections are 'for'.

Ritual is a concept familiar to anthropologists and political historians, ${ }^{3}$ but much less so to contemporary legal or political theorists. Yet ritual naturally emerges from and illuminates the experience of democratic culture. That illumination can reflect light upon — and hence aid our understanding of — the law's role in

1 g.orr@law.uq.edu.au.

2 ACTV v Commonwealth (1992) 177 CLR 106, uncovering an implied freedom of political communication, is the best known example. The twin franchise cases of Roach $v$ Electoral Commissioner (2007) 233 CLR 162 and Rowe $v$ Electoral Commissioner (2010) 243 CLR 1 are more recent instances. Mild in their effect, the cases have still been savaged by champions of the originalist intention to leave the field to Parliament alone. For example, James Allan, 'The Three Rs of Recent Australian Judicial Activism: Roach, Rowe and (No) 'Riginalism' (2012) 36 Melbourne University Law Review 743.

3 For example, James Frazer, The Golden Bough: A Study in Magic and Religion (Macmillan, 1963); Mark W Brewin, Celebrating Democracy: The Mass-Mediated Ritual of Election Day (Peter Lang, 2008). 
democracy. Whilst the ritual dimension may often be overlooked in rationalist accounts of law-making, it is inescapable. The laws and institutions we adopt will necessarily shape and constrain the ritual experience. Without appreciating this, we cannot fully understand the social power and place of elections and the laws and institutions that underlie them.

I will shortly offer definitions of the concept, then attempt some positive demonstration of my claims about the importance of a ritual understanding. But first, it is useful to take a quick stock of the dominant theoretical approaches and presumptions that have been applied to the law of electoral politics. Broadly put, those approaches are the realist, and the liberal. They are fairly hard-headed, in the sense that they are usually invoked to drive law reform or judicial review in the area. My desire is not to supplant the realist and liberal approaches with an approach drawing on ritual, but to augment them.

Take first the self-styled realist approach. Popular here and abroad, this strand of thought is economistic, and essentially pragmatic to the point of cynicism. In this view, electoral politics is seen as a Schumpeterian competition amongst political elites. ${ }^{4}$ The law of electoral politics must be calibrated to minimise negative effects of gaming by self-interested incumbent MPs and parties, and to maximise positive effects such as accountability. ${ }^{5}$ Electoral democracy in this approach is depicted as having no ends in itself; it is seen as just an institutional method to soften or compromise the elite rule of representative government. In Schumpeter's declaration: 'Democracy is a political method [i.e.] a certain type of institutional arrangement for arriving at [governmental] decisions and hence incapable of being an end in itself' ${ }^{6}$

The law's role within all this is as a boundary-rider, trying to limit undemocratic harms that may arise if democracy becomes the discretionary plaything of self-interested and passing legislators and administrations. Richard Posner epitomises this approach, in his explicitly anti-trust model for regulating electoral democracy. ${ }^{7}$ From this understanding we derive things such as the independence of electoral authorities that run elections, and the tendency for courts, worldwide, to place limits around Parliament's power to make electoral legislation. ${ }^{8}$

4 Joseph Schumpeter, in three seminal chapters in Socialism, Capitalism and Democracy (Routledge, new ed, 1994) chs 21-23, laid out his critique of classical liberal democracy.

5 Electoral accountability is crude, but without it other forms of accountability (for example, parliamentary and media oversight of government, or the reflexive attention of leaders to public opinion) would be much weaker.

6 Joseph Schumpeter, Socialism, Capitalism and Democracy (Routledge, new ed, 1994) 242. Posner explicitly embraces Schumpeter, though he paints his approach as pragmatic rather than elite democracy. See Richard A Posner, Law, Pragmatism and Democracy (Harvard University Press, 2003) chs 4-6.

7 Richard A Posner, Law, Pragmatism and Democracy (Harvard University Press, 2003) chs 4-6. See Richard Pildes, 'Competitive, Deliberative and Rights-Oriented Democracy' (2004) 3 Election Law Journal 685.

8 Even absent an explicit bill of rights. See ACTV $v$ Commonwealth (1992) 177 CLR 106, Roach $v$ Electoral Commissioner (2007) 233 CLR 162 and Rowe v Electoral Commissioner (2010) 243 CLR 1. Such cases manifest 
In the other, liberal approach, the law plays a more normatively constructive, rather than a merely boundary-riding role. The law is depicted as part of a quest for deeper values or loftier purposes, derived from liberal political philosophy. These purposes are political liberty, equality and deliberation. That is, the law can aim to encourage participation and political freedoms, it can seek to advance political equality in an otherwise unequal society and it can seek to foster informed and reflective public deliberation (although this last role is often overlooked or sublimated). ${ }^{9}$ Now there is obviously room for tension amongst these goals, especially between liberty and equality. (For example, how far can we restrain money in politics in the interests of egalitarianism, and is it right to compel people to the polls to create a more inclusive electoral system?) But together, these three values provide a benchmark of liberal democratic values to help craft the substance of the law. Straddling the realist and liberal camps, James Gardner succinctly explained recently that 'election law bridges the gap between our aspirations for, and the frequently messy reality of, our political lives' ${ }^{10}$

What I wish to argue in this chapter is that there is another, less instrumental, ${ }^{11}$ yet no less 'real' or even pragmatic way of thinking about the law of electoral politics. And that is to examine the ritual dimension of it all. ${ }^{12}$ No-one would deny that the traditions of the opening of Parliament, for example, form obvious, public law rituals. But I want to make a much broader and, I hope, more interesting claim that there is an element of ritual all the way down. Ritual concerns the repeated patterns of everyday life, in this case of recurrent electoral activity. Law, whether it knows it or not, plays a role in opening up space for, constraining or guiding that ritual element. We should not be surprised, therefore, to find ritual manifest by and, in some cases embedded in, not just democratic practice, but throughout public law.

As a working definition, I borrow Murray Edelman's definition of ritual as any 'activity that involves its participants symbolically in a common enterprise, calling their attention to their relatedness and joint interests in a compelling way'. ${ }^{13}$ To this we must add, however, the need for a ritual to be something

\footnotetext{
the idea that the electoral self-interest of parliamentary majorities requires supervision. John Hart Ely, Democracy and Distrust: A Theory of Judicial Review (Harvard University Press, 1980).

9 Compare Richard Pildes, 'Competitive, Deliberative and Rights-Oriented Democracy' (2004) 3 Election Law Journal, and Andrew Geddis, 'Three Conceptions of the Electoral Moment' (2003) 28 Australian Journal of Legal Philosophy 53. Of these, the liberty and equality 'visions' are most developed, albeit in tension. Some doubt that electoral campaigns, however well-regulated, can be deliberative. James A Gardner, What are Campaigns For?: The Role of Persuasion in Electoral Law and Politics (Oxford University Press, 2009).

10 James A Gardner, ‘Election Law as Applied Democratic Theory' (2012) 56 St Louis University Law Journal 689.

11 Less instrumental in that ritual considers things such as elections as events in themselves, and not merely unavoidable steps in some broader governmental process.

12 I first sketched this in 'The Ritual and Aesthetic in Electoral Law' (2004) 32 Federal Law Review 425. The present essay is part of a larger book on 'Ritual and Rhythm in Electoral Systems' (Ashgate, 2015).

13 Murray Edelman, The Symbolic Uses of Politics (University of Illinois Press, 5th ed, 1985) 16.
} 
patterned, repeated or rhythmic. Ritual, so understood, is intimately connected to common experiences (albeit ones that different people may respond to, intellectually and emotionally, in different ways). Rituals carry meanings, but they are not limited to occasions exhibiting grand themes like the sacred or the constitutive, which we find in ceremonial and liminal moments of creation or loss. Elections in a settled democracy are, simultaneously, both significant (re) constitutive moments and relatively routine acts of public participation and administration.

\section{Rituals and rhythms - and their relationship with myths, symbols and aesthetics}

As regularised events, elections have an inescapably ritual dimension. Elections are nothing if not public events, experienced by citizens and political actors alike. Ritual has classically been understood in semi-religious terms, particularly through notions such as rite and myth in the sense of legend. More secular understandings of ritual emphasise theatre and myth in terms of the symbolism of public life. Elements such as rite and theatre can certainly be identified in moments of solemn or high political behaviour, whether they be the formal dissolution of Parliament and issuing of electoral writs, or the gatherings at tally rooms and concession speeches that dominate election night. But ritual is not exhausted by these moments of political behaviour. The ritual that most intrigues me is a much more quotidian beast, such as the experiences at the polling station. But before we get to those everyday experiences, it is worth contrasting ritual with some key related concepts of myth, symbolics and aesthetics.

The religious or transcendent connotations of rite and ritual have been explored in both traditional anthropological literature and, more recently, in the notion of civil religion. ${ }^{14}$ The original insight of civil religion was to reveal how public and political order can be imbued with transcendent meaning: politics as religion. A more recent focus, most obviously in the US, has been on the public aspect of religion and how its cleavages are written into political order: religion as politics. ${ }^{15}$ Both the traditional anthropological approach, and the civil and public religion viewpoints draw our attention to a broader baggage often transported by ritual: the notion of myth.

14 With roots in Robert Bellah, 'Civil Religion in America' (1967) 96(1) Dadalus 1.

15 Compare Robert Withnow, The Restructuring of American Religion (Princeton University Press, 1988) ch 10, identifying a conservative and liberal civil religions and theologies. 
Myth is carried by and replicated not just through explicit stories, but also in the more implicit practices we transmit across generations. Democracy revels in myth as much as any other system of government. (Indeed, to Claude LéviStrauss, the political ideology of contemporary liberal societies is of an order with the myth and religion of older societies). ${ }^{16}$ There are stories of forgetting, especially in foundational myths. Australians are proud of their relatively rapid and egalitarian expansion of the vote in the 19th century. That expansion took late 19th century Australia, in a handful of decades, from a property-based franchise which countenanced multiple voting, through the evolution of oneman, one-vote, and onto adult suffrage with the enfranchisement of women around the time of federation. But that pride requires sublimation of the fact that most Indigenous Australians waited up to 60 years longer to gain this first order liberal right. ${ }^{17}$ Similarly, does the average British or North American person today remember that women were denied the vote by law until 1918-20, barely one lifetime ago ${ }^{18}$

Most democracies espouse their own particular, inflected legends of democracy, whether of loss, change or renewal. These legends extend beyond simple tales of movements demanding popular and local sovereignty, to include the role of the media and foreign affairs. Many Americans, for instance, believe that the broadcaster Walter Cronkite declared the Vietnam War unwinnable, channelling the fears of the zeitgeist, and thereby sealed the fate of the conflict. This is pure myth. ${ }^{19}$ Australians, depending on whether they are social democrats or conservatives, invest the short-lived Whitlam government with either the status of Camelot made real, or as a warning of the limits of politics and governmental ambition. Each of those positions on the Whitlam government makes sense in itself, but is overstated relative to the administration's short-life (1972-75). Nonetheless, the government's dramatic undoing — it was controversially dismissed by the Queen's representative in Australia - fuses these conflicting narratives, of Camelot-lost and a failed government, into an even larger legend.

Myth generates meaning through the use of bold colours and big canvasses, by lionising or demonising particular key characters or major events. A ritual such as a presidential inauguration, or a leader claiming victory on election night, may recall these wider stories and histories. But whilst myth can colour the way we read and experience rituals, rituals are not the agents of myth. Rather, rituals tend to carry embedded meanings: meanings they emblemise or symbolise. An

16 Claude Lévi-Strauss, Structural Anthropology (Claire Jacobson trans, Basic Books, 1963) 306.

17 Adrian Brooks, "'A Paragon of Democratic Virtues?": The Development of the Commonwealth Franchise' (1993) 12 University of Tasmania Law Review 208.

18 Even then, British women did not enjoy equal suffrage with men until the Representation of the People (Equal Franchise) Act 1928 (UK).

19 W Joseph Campbell, Getting It Wrong: Ten of the Greatest Misreported Stories in American Journalism (University of California Press, 2010) ch 5. 
example of this is the way that polling routinely takes place in schools, whose significance we will examine shortly. The symbolic meanings inherent in rituals differ from myth, because ritual is less singular, and typically more routine. Ritual is the fabric of everyday life; myth is often cartoonish and perpetuated by a kind of history-for-beginners. The power of ritual lies both in its intimacy (of the lived experience of campaigns and voting) or in its repetition (the cycle of an election summonsed, its results declared, a new government or president commissioned).

There is another related concept, the aesthetic, which also requires a little explanation and exploration. Aesthetics is an ancient branch of thinking; traditionally it was a source of virtue. Legal aesthetics is a vibrant and broad ranging body of thought, which can cover everything from the relatively concrete - such as the architecture and design of Parliaments and court buildings - through to reflections on how different notions of time and space are inescapably embedded in understandings of, say, religious freedom. ${ }^{20}$ Discussions of legal aesthetics, whether in public or private law, however, can be fraught. They can risk collapsing into formalism, in the sense of fetishising the formal neatness of legal structures or logic. They can even dissolve into a striving for a kind of beauty informed by poetic but mystical, even totalitarian, impulses. ${ }^{21}$

But we cannot think about ritual without a notion of the aesthetic in the sense of fit or harmony. This encapsulates both a concrete or sensory experience of fit, and also fit in the sense of proportionality. Sensory examples are not difficult to find, once one digs a little into the law. In election campaigns, for instance, we find concrete regulation in everything from local government strictures on the size and location of 'vote for me' posters, through to bans on displays, demonstrations and hubbub near polling booths. In the more abstract sense of proportionality, we find different political aesthetics implicit in different approaches to regulating election finance and preferred (or frowned upon) forms of campaigning. Compare, for instance, the American laissez-faire model of expenditure, with the British law banning all paid political broadcasts but granting airtime instead for substantial 'party political broadcasts' ${ }^{22}$

Now, of course, these examples all inter-relate with the other theories for conceiving of electoral rules. Sometimes judges frown on limitations on the size

\footnotetext{
20 Benjamin L Berger, 'The Aesthetics of Religious Freedom' in Winifred Sullivan and Lori Beaman (eds), Varieties of Religious Establishment (Ashgate, 2013).

21 Consider D'Annunzio's constitution for the province of Carnaro, in which music was a core principle of the state. Of ten corporations (or sectors) one was reserved as a 'votive offering to the genius of the unknown' and represented by a public flame to the ideal of Fatica senza Fatica ('Work without Toil').

22 The UK is not alone: Israel and New Zealand have similar regimes. The UK goes further in erecting a year round limitation on paid political — nor merely electoral — broadcasts. Australia briefly borrowed the electorally puritan model before the High Court struck it down. See ACTV v Commonwealth (1992) 177 CLR 106.
} 
or number of electoral posters on private property, by reasoning that liberty interests prevail over amenity. ${ }^{23}$ The 'cordon sanitaire', established by the rule against campaigning near or inside polling booths, ${ }^{24}$ creates an aesthetic experience of quiet order, a sense of deliberativeness as well as a potential repose for deliberation for any electors yet to decide how to direct their preferences. The valorising of the liberty of money in the US, as opposed to the more egalitarian British approach to political finance, overshadows aesthetic considerations such as the ideal forms of political speech. My point is not that aesthetic concerns are overt drivers of regulation, but that an aesthetic is involved in each issue and approach, even if only as a by-product. We cannot think about the ritual or experience of a campaign with streets festooned with election placards (or not), of voting in a hubbub (or in a quite ballot booth) or of campaigns flush with television advertisements (or starved of them), without considering the aesthetic element.

\section{The rituals of election day and polling}

Armed with an understanding of ritual as patterned actions and shared experiences, we can now turn to more practical questions. What of the actions that constitute elections, especially the central acts of casting and counting votes? How does law - broadly understood to include institutional practice and custom, as well as black-letter rules - set up the ground for ritual in electoral politics?

Let us take the act of voting, which we have come to take for granted. Les Murray finished his poem My Ancestress and the Secret Ballot, 1848 and 1851 with the metaphor of the ballot booth becoming 'a closet of prayer'.$^{25}$ Not so much a command to the gods who govern us, but a hope sent forth in good conscience. Yet, 150 years after the emergence of the secret ballot, in his book Voting Rites, Ron Hirschbein lamented that voter turnout in the US had dwindled, relative to headier days. He blamed this only in part because voting 'no longer offers the illusion that it is instrumental (politically efficacious)'. The deeper problem, Hirschbein claims, is that 'electoral politics is bereft of expressive value: Casting a ballot no longer provides ritualistic gratification and hardy entertainment.' ${ }^{26}$ Voting, Hirschbein lamented, had lost too much of its affective, as well as its

\footnotetext{
23 Liberal Party of Australia (Western Australian Division) Inc $v$ City of Armadale [2013] WASC 27. Yet the national law forbids such activity as chalking electoral arguments on roads, or projecting slogans on buildings. Commonwealth Electoral Act 1918 (Cth) s 334.

24 Commonwealth Electoral Act 1918 (Cth) ss 335, 340-1. See also s 328.

25 Les Murray, Subhuman Redneck Poems (Duffy \& Snellgrove, 1996). A copy of the poem also opens Mark McKenna's revisionist account of the ballot, 'Building a "Closet of Prayer" in the New World: The Story of the "Australian Ballot"' in Marian Sawer (ed), Elections: Full, Free and Fair (The Federation Press, 2001) 45.

26 Ron Hirschbein, Voting Rites: The Devolution of American Politics (Praeger, 1999) 2 (emphasis altered).
} 
effective, dimensions. It had lost 'its former liturgical fullness [and] carnival spirit' ${ }^{27}$ Chronicling the history of election day in Philadelphia, Mark Brewin similarly highlights a loss of the 'public celebration' as the physical element is transformed into a ritual mediated by electronic communication systems. ${ }^{28}$

Jon Lawrence, another political historian, but in this case writing from a UK perspective, warns against simplistic or romantic historical comparisons, whilst admitting that it is easy to read 19th century UK hustings 'at one level ... as ritualised celebrations of Britain's unequal, hierarchical society' ${ }^{29}$ The historian's insight seems to be that everything has changed: legally, with the advent of the mass franchise, and technologically, with the bureaucratisation of modern life. Yet elections remain a time when the governing class - albeit now a professional political class rather than a class defined by inherited privilege ${ }^{30}$ - temporarily faces a public humbling. The largesse of vote-buying is now done through public promises rather than private bribery, ${ }^{31}$ and the heckling from the crowd is replaced by talk-back radio or television interviewers. But elections remain a demotic ritual.

Without any stretching or romanticism, we can still see election day as a unique communal event. Traditionalists might yearn for some transcendent 'liturgical fullness', but election day is not bereft without it. Some Australians are habituated into participating, less by intrinsic desire and more by legal compulsion - corralled into participating not, as Athenians were, by a cord dyed red, but by the vague threat of a $\$ 20$ fine. Yet a communal ritual remains, even if some experience it as a political confessional whilst others feel it to be a public duty or chore. ${ }^{32}$ The ritual is primarily built up in the patterned behaviour - what transpires in the internal reflections of different individuals is another matter. In this more everyday understanding of ritual, we only need to describe the scene of polling day in Australia to see its ritual dimensions. The local scouts and charities set up their sausage sizzles and cake stalls; the party activists wrap bunting along the school gates; ${ }^{33}$ the elector quickens her pace as she dodges (or politely accepts) offers of 'how-to-vote cards', before entering

\footnotetext{
27 ibid 130

28 Mark W Brewin, Celebrating Democracy: The Mass-Mediated Ritual of Election Day (Peter Lang, 2008) ch 9.

29 Jon Lawrence, Electing our Masters: The Hustings in British Politics from Hogarth to Blair (Oxford University Press, 2009) 6.

30 One might say a political class 'mostly not defined by inherited privilege': the present UK Prime Minister and Deputy Prime Minister are Old Etonians; in the US, dynasties such as the Kennedys are superseded by the Bushes. But they are exceptions, not rules.

31 Graeme Orr, 'Dealing in Votes: Regulating Electoral Bribery' in Graeme Orr et al. (eds), Realising Democracy: Electoral Law in Australia (The Federation Press, 2003) 130.

32 Just as, to extend the religious metaphor, some Christians take communion as a sacrament, others out of unreflective habit.

33 But not too close. Commonwealth Electoral Act 1918 (Cth) s 40 forbids such colour within six metres of the entrance to the sanctity of the polling booth. In two jurisdictions, Tasmania and the ACT, the aesthetic of repose extends wider, to a 100 -metre cordon sanitaire around polling stations.
} 
the calm of the polling station to retire to a booth and place pencil marks on the official ballot papers. All this, to varying degrees, is a product of law, whether black-letter or institutional policy choices.

Citizens thus gather - or rather they are summonsed by the law of compulsory participation that we call compulsory voting — on the one day every three or so years that our secular society comes together. This periodicity is laid down constitutionally: three years nationally, four years for most States and Territories. ${ }^{34}$ They wait in line after running the gauntlet of how-to-vote cards, which are themselves a product of preferential voting laws. ${ }^{35}$ They find themselves milling in the quiet of the polling booth itself, a place whose repose is protected by law. ${ }^{36}$ Finally, they have their names marked off the roll, ballots completed by trusty pencil and consigned with a wish or curse to a secure ballot box. All of this, down to the pencil, is safeguarded by legal regulation. ${ }^{37}$

Certainly, it might be objected that what scouts and party volunteers do is not legally determined in any strong sense. But in a profound sense it is shaped and enabled by law. Imagine a society that moved to internet voting, as some have advocated for noble reasons relating to maximising formal participation. There would be no physical event, presumably no 'election day' as such, just a final time limit to lodge one's electoral choices electronically. Elections would become an even more private and transactionalised activity. ${ }^{38}$ Something significant of a communal nature would be lost. Paradoxically, the more secular and marketoriented Western nations become, the more polling day stands out as the oneday when a society comes together.

Rituals and beliefs, of course, bubble up or are inherited from many sources. Those sources may co-mingle; they may also clash. The secular 'civil religion' of electoral democracy aims to bring citizens together for at least one occasion every several years. Yet its demands are sometimes incompatible with other belief systems and practices. Most obviously, Jehovah's Witnesses do not partake of the electoral ritual, because they honour only their God and not secular political institutions. Compulsory voting in Australia accommodates such conscientious objections, but only if they stem from a shared creed and not an idiosyncratic belief, however sincerely held. ${ }^{39}$

\footnotetext{
34 For example Australian Constitution ss 28, 32 (three-year cycle for national elections).

35 Except in Tasmanian elections, where they are banned. Electoral Act 2004 (Tas) s 198.

36 Commonwealth Electoral Act 1918 (Cth) ss 335, 340-1.

37 Of course the ritual differs if one votes by post, at home. It is more private and the nesting of envelopes within envelopes reflects a bureaucratic promise as to one's anonymity. The ritual differs in its ease and inflection, but it is still, palpably, a ritual.

38 Compare Heather Lardy, 'Modernising Elections: The Silent Premises of the Electoral Pilot Schemes' (2003) 1 Public Law 6 (critiquing moves to extend postal balloting).

39 Douglas $v$ Ninnes (1976) 14 SASR 377 at 382-3.
} 
Praises are often sung for the fact that Australian law has long mandated that election day be a Saturday. In comparison, general elections are held on a Thursday in the UK and a Tuesday in the US. Saturday elections expressed an egalitarian value, as working hours had been reduced to a half-day and, for most permanent employees, Saturday became a work-free day altogether. Voting in Australia is thus a more leisurely affair than in countries where workers have to duck into polling stations on their way to or from work. Voting on working days also leads, as we see in the US, to irresistible pressure to offer early voting to everyone, which detracts from the ritualistic purpose of having a polling day at all.

Yet weekend voting presents drawbacks, as many religions reserve Saturdays or Sundays for worship. The September date chosen for the 2013 Australian election coincided with Yom Kippur, the most sacred day in the Judaic calendar. Religious observance entitles electors to an early or postal vote, but the result was that Jewish Australians could participate in their religious ritual and the formal franchise, yet they could not partake fully in the democratic ritual. In contrast, the law (where terms are fixed) and leaders of all stripes (where election dates are open), avoid elections overlapping with the finals of the two major football codes. ${ }^{40}$ The Prime Minister offered this half-apology: 'I do understand the significance of the day in question for the Jewish community. But there would be many of my Melbourne Jewish friends who would also understand the significance of AFL grand final day. ${ }^{41}$ So it is that two great mainstream competitive rituals, sporting finals and electoral politics, are accorded separate spotlights, but other cultural practices can be neglected.

And just where do we vote? Admittedly Australian law has little explicitly to say on the point - other than frowning on 'licensed premises' ${ }^{42}$ But what the law does not do is notable. It does not say, as it well might if it cared most for administrative ease, that electors are to front at electoral offices or other government buildings. If it did so, it would reinforce a statist element to the ritual of voting. Instead, it leaves the matter in the discretion of the electoral commissions. In the US the matter is dispersed, like much electoral administration, across county and even city levels. Underfunded officials compete to rent suitable spaces. One official in California told me of resorting to using a motorcycle dealership. A condition of hiring was that sales were to cease that day: to mingle the rituals of commerce and politics would be too much.

\footnotetext{
40 Australian Rules (AFL) and Rugby League.

41 Julia Gillard, quoted in Ben Packham, 'Julia Gillard sets September 14 Election Date', The Australian (online), 30 January 2013, http://www.theaustralian.com.au/national-affairs/gillard-sets-september-14election-date/story-fn59niix-1226565039127.

42 Commonwealth Electoral Act 1918 (Cth) s 205. In rural towns, the pub may be the only 'public' building. The issue was a particular concern a century ago, because alcohol was linked to vote-buying through 'treating' and because it was seen as unseemly for newly enfranchised women to have to vote in such a male domain.
} 
But the proprietor also insisted that one voting compartment be set up close to a fancy bike, so that electors could enjoy using the voting machine whilst straddling a road machine!

In Australia, electoral commissions overwhelmingly choose public halls - and school halls more than religious halls, for reasons that are both obvious (church/ state and inter-religious sensitivities) and less obvious but still profound. What else, besides compulsory voting, symbolises equal citizenship more than compulsory education? Just as we all wandered to school every day as children, so as adults we wander back to school halls every three years to vote. ${ }^{43}$ A similar aesthetic, or sense of proportion between the civic nature of the ballot and the status of school halls, is explicitly written into New Zealand law. ${ }^{44}$

The secrecy of the ballot is another obviously important legal form, of significance not just to poets dreaming of 'a closet of prayer'. The secret ballot laws are echoed in the action of every elector who accepts all - or none of the how-to-vote cards on offer, thereby disguising her voting intentions. ${ }^{45}$ Those cards, distinctly Australian artefacts of last minute campaigning, have survived laws putting party labels on ballots. ${ }^{46}$ This survival is partly because the law about casting a formal ballot under preferential voting in Australia is more complex than either the first-past-the-post or the party list systems used elsewhere. How-to-vote cards also survive because the larger parties believe it gives them an advantage, since they can mobilise sufficient supporters and money to afford this type of canvassing. Otherwise they could amend the law against any partisan material being posted in the polling station, and permit every candidate to have their how-to-vote card displayed prominently.

\footnotetext{
43 More developed in Graeme Orr, “The Ritual and Aesthetic in Electoral Law' (2004) 32 Federal Law Review 438. 44 Electoral Act 1993 (NZ) s 156.

45 How-to-vote cards are replicas of ballots, adorned with photos of aspiring MPs and their leader, showing electors how to direct preferences for that candidate or party.

46 Commonwealth Electoral Act 1918 (Cth) s 214 (ballot labelling) and part XI (registration of parties) date to 1983 .
} 


\section{Election night and the count: Rhythms and theatre}

Consider also the debate about abandoning the tradition of a central 'tally room'. To reduce costs, budgetary minded electoral authorities now favour a purely dispersed, electronic method of disseminating election results. Australian politicians and journalists, however, have fought to keep the theatre of a tally room, as an official or central stage. ${ }^{47}$ UK electoral administration, by contrast, is decentralised. But it generates something even more ritualistic in its local ceremonies for the public declaration of constituency results, which take place during the early hours of the morning as election night counts unfold. Counting to resolve the Westminster Parliament is relatively simple, since the law provides for first-past-the-post voting. And UK postal votes have to be received by the close of polling on election day. ${ }^{48}$ As a result, even with hand-counting, votes can be conclusively tallied within several hours.

Candidates for Westminster are invited and expected to attend the public declaration of their race, in their community, as the returning officer (often a local mayor) intones the votes received. With different supporters mixing together, and Ministers rubbing shoulders with joke candidates, a captivating ritual of surprise, humiliation and triumph ensues. ${ }^{49}$ In turn, the smaller constituencies vie to become the first in the nation to declare their result, in a kind of race within the race. ${ }^{50}$ This may be done to gain passing notoriety for the district on a night of national attention, or simply out of pride in the efficiency of the count. The idea of a race to finish the count would make no sense in Australia. Here, the laws governing the formality of preferential voting are more complex, and any sense of rushing to a declaration would suggest anything but efficiency.

In any event, under Australian law, provisional votes have to be checked, and postal ballots can dribble in until 13 days after polling day. ${ }^{51}$ As a result, there is no conclusive public moment; rather, provisional results are released and updated, race by race, over election night and cumulative swings are calculated by computer-assisted psephologists, as if studying seismological data of how much the (political) ground shifted. In very close elections, the fate of a

47 See, Joint Standing Committee on Electoral Matters, Parliament of Australia, Inquiry into Certain Aspects of the Administration of the Australian Electoral Commission (2007) ch 4.

48 The Electoral Commission (UK), 'Voting by Post', http://www.aboutmyvote.co.uk/how_do_i_vote/ voting_by_post.aspx.

49 The cover of Lawrence's book (Jon Lawrence, Electing our Masters: The Hustings in British Politics from Hogarth to Blair (Oxford University Press, 2009)) illustrates this, with a photograph of Prime Minister Blair attending his Sedgfield electorate declaration in 2005, flanked by anti-Iraq-war candidates. One, a father of a dead soldier, is delivering a speech, the other is wearing a hat labelled 'BLIAR'.

50 Chris Mullin, A View From the Foothills: The Diaries of Chris Mullin (Profile Books, 2009).

51 For example, Commonwealth Electoral Act 1918 (Cth) s 266. 
government may hang in the balance for many days. In the US, to give a further contrast, a plethora of different voting technologies ensure a relatively quick count. Indeed, a shift to all electronic voting could in theory lead to election results being known instantaneously, at the flick of a switch or key.

This is what currently happens in Australian Senate elections. To cope with the legal complexity of Hare-Clark proportional representation, ballots are counted by computer. ${ }^{52}$ However, computerised ballots are not cast by voters; paper ballots are converted to electronic format by data-entry operators after polling day. This process is painstaking, so Senate results become something of an afterthought. Cynics might say that this leisurely process mimics the Senate itself, with its six-year sinecures fixed in the Constitution. It certainly reinforces the constitutional position of the Australian Senate as a secondary house of review. In contrast, first-past-the-post voting in the US ensures that attention to Senate races ranks ahead of the House and second only to the presidential race. Yet, through all these different rhythms - dependent in large part on the different electoral laws, policies and technologies in place - one ritual is common: the election night party of the partisans. ${ }^{53}$

\section{After the electoral deluge: Rites of inauguration}

Earlier I explained that 'ritual' should not simply invoke the language of 'rites', however tempting the analogy may be. A 'rite' is a narrower concept associated usually with solemn (religious) tradition, typically bearing a clear relationship with a point of transition. Frederick Damon, an anthropologist who explored the phenomenon from an American electoral perspective, argued that US elections were seminal rites of passage, mirroring rites in societies more overtly driven by custom. In effect, he portrayed US presidential elections as installation rites featuring a particular set of rhythms. ${ }^{54}$

First, the candidates declare or announce themselves, separating or distinguishing themselves and entering a period of 'masquerade', which includes the primary season. Then comes a period of social abnormality: the general election campaign inverts the normal order of politics, which is compromise and give-and-take. This generates a form of extreme testing, a winner-takes-all battle, which culminates in the election. After the election outcome follows a prolonged period when the victor moves to heal wounds, prior to the most formal stage of the entire

\footnotetext{
52 Technically, Senate electors do not just select a party list, but rank all candidates.

53 Captured in Australia in David Williamson's 1971 play, Don's Party (which was released as a movie in 1976).

54 Frederick A Damon, 'What Good are Elections: An Anthropological Analysis of American Elections (2003) 1 Taiwan Journal of Anthropology 39, especially at 53-62. Damon, at 62-71, also analogises US twoparty electoral politics to 'joking relations' (a custom of the Kaguru people of east Africa, where groups spar via mutual insults, to purify or rectify social tensions or problems).
} 
ritualistic process, the ceremony of inauguration. It may be no coincidence that the latent healing period overlaps with the festive season (statute sets US elections for early November, ${ }^{55}$ terms of office are set constitutionally). ${ }^{56}$ The latter two stages - healing then inauguration - are obviously pronounced in the US presidential model. Although a partisan elected official, the President is also the head of state and hence meant to be a unifying figure for the republic.

Most famously, the President has to be sworn in and inaugurated in Washington DC by noon on the $20^{\text {th }}$ day of January. ${ }^{57}$ Originally this was 4 March, an emblematic date representing the day the US Constitution came into effect. ${ }^{58}$ Of course, the several-month wait between election day and inauguration reflected pragmatics more than any deeper design: the electoral college had to formally gather, and transportation across a large country was not easy. But all this is to say that ritual may spring up irrespective of conscious intention. The extensive wait permits not just a rite of healing and transition, but a now elaborately planned day that mixes a focus on the meaning of a national union and the formation of government, with a touch of to-the-victor-goes-the-spoils. On a less exalted note, inauguration renews the beltway culture, as political backers and insiders come together to participate in forming the fledgling administration.

In contrast, in the UK and Australian models, the law keeps election campaigns relatively short. With no directly elected executive, and shorn of laws mandating primary elections, parliamentary elections are centred less on individual candidates and more on party-dominated responsible government. A new Prime Minister is moved through the caretaker period onto the swearing in of their ministry, before the Queen's representative, more quickly and quietly than would be countenanced in the US system.

However there are occasions where parliamentary, as opposed to party, government reasserts itself. This was obvious after the inconclusive, hung elections of 2010 in both Canberra and Westminster. In each case, ad hoc rituals of inauguration (some might say marriages of convenience) were played out. In the UK it was the fairly mannered announcement, less than a week from election day, of a Conservative-Liberal Democrat pact. This was formalised in an initial seven-page agreement, ritually adopted with a handshake on the steps of Number 10 Downing Street. In Australia, the process was more protracted, with a new ministry taking over three weeks to assemble, as both the caretaker

55 The first Tuesday after the first Monday in November, in even-numbered years (2 USC ss 1, 7 and 3 USC s 1).

56 See United States Constitution, 20th amendment. (Prior to this, they began on 4 March, symbolically the date the Constitution first took effect.)

57 ibid. Exceptionally, as happened to Barack Obama in 2013 when 20 January was a Sunday, the president may have to be sworn in on a Sunday, then inaugurated the next day. Although inauguration day is not a holiday, its separation from the Christian day of rest positions it as a civic celebration distinct from any religious connotations.

58 Not to be confused with US Constitution Day in September, marking the 1787 signing of the original document. 
Prime Minister and Opposition Leader sought to woo six cross-benchers. Several agreements were concluded in series with different players, before the chaotic day of announcements by two-out-of-three rural independents that they would support the continuation of a Labor government. These ad hoc rites of incorporation worked less well than in the US: the administrations formed have lacked the sense of legitimacy that even President Bush Jr assumed, despite his election in 2000 lacking a nationwide vote majority and requiring an extraordinary court decision to confirm it.

\section{Conclusion: The strands of democracy}

All we do is marked by rhythms. From the office worker who takes her daily coffee a certain way in the same cafe, through to the act of voting, by pencil on secret ballot in a cardboard booth each three years, to the communal singing of the national anthem before a sporting contest. These are all rituals, albeit rituals of different orders of publicness or privateness, and with different levels of inherent meaning. The cafe is a public place and, in her particular choice of venue and bean, the coffee drinker may be quietly projecting something about herself. But she is essentially enjoying a solitary ritual. The public meanings of the quasi-enforced observance of the anthem, weaving nationalism and the bombastic glories and hopes of a sporting encounter, hardly need decoding. Ritual, defined as shared, patterned behaviour, is everywhere.

This essay has sought to argue for an attention to ritual, alongside related concepts such as myth and aesthetics, as central to any rounded understanding of electoral democracy as it is contoured by public law. The illustrations we have discussed are suggestive rather than comprehensive. The samples given here have been drawn from polling day and its aftermath, rather than say the process of inception of fresh elections or the campaign itself. The examples we have encountered have drawn on several common law systems, both parliamentary and executive.

In discerning differences, both across time and space, we can see that once we leave both the meta-narratives of liberal democracy (of liberty, equality and deliberation) and the hard-nosed 'realist' account of elite democracy, there is another world to explore. Exploring it requires tools beyond the rhetoric of liberal legal and political philosophy or the modelling of public choice theorists. It requires an eye for observation of routines and an ear for the poetry of the everyday. That is not meant to sound grandiose; quite the reverse. Electoral democracy and its legal and institutional ordering is just one strand of public life. But it is a strand connected and integral to many others, and it is a strand of many colours. 
This text taken from Law and Democracy: Contemporary questions, edited by Glenn Patmore and Kim Rubenstein, published 2014 by ANU Press, The Australian National University, Canberra, Australia. 